\title{
The Transduction Channel TRPM5 Is Gated by Intracellular Calcium in Taste Cells
}

\author{
Zheng Zhang, ${ }^{1}$ Zhen Zhao, ${ }^{1}$ Robert Margolskee, ${ }^{2}$ and Emily Liman ${ }^{1}$ \\ ${ }^{1}$ Department of Biological Sciences and Program in Neuroscience, University of Southern California, Los Angeles, California 90089, and ${ }^{2}$ Department of \\ Neuroscience, Mount Sinai School of Medicine, New York, New York 10029
}

\begin{abstract}
Bitter, sweet, and umami tastants are detected by G-protein-coupled receptors that signal through a common second-messenger cascade involving gustducin, phospholipase C $\beta 2$, and the transient receptor potential M5 (TRPM5) ion channel. The mechanism by which phosphoinositide signaling activates TRPM 5 has been studied in heterologous cell types with contradictory results. To resolve this issue and understand the role of TRPM5 in taste signaling, we took advantage of mice in which the TRPM5 promoter drives expression of green fluorescent protein and mice that carry a targeted deletion of the TRPM5 gene to unequivocally identify TRPM5-dependent currents in taste receptor cells. Our results show that brief elevation of intracellular inositol trisphosphate or $\mathrm{Ca}^{2+}$ is sufficient to gate TRPM5dependent currents in intact taste cells, but only intracellular $\mathrm{Ca}^{2+}$ is able to activate TRPM5-dependent currents in excised patches. Detailed study in excised patches showed that TRPM5 forms a nonselective cation channel that is half-activated by $8 \mu \mathrm{M} \mathrm{Ca}{ }^{2+}$ and that desensitizes in response to prolonged exposure to intracellular $\mathrm{Ca}^{2+}$. In addition to channels encoded by the TRPM5 gene, we found that taste cells have a second type of $\mathrm{Ca}^{2+}$-activated nonselective cation channel that is less sensitive to intracellular $\mathrm{Ca}^{2+}$. These data constrain proposed models for taste transduction and suggest a link between receptor signaling and membrane potential in taste cells.
\end{abstract}

Key words: transient receptor potential; bitter; sweet; inositol trisphosphate; ion channel; calcium

\section{Introduction}

Taste receptor cells are modified epithelial cells that transduce sensory input into changes in the release of neurotransmitter onto afferent nerve fibers. For bitter, sweet, and umami tastants, stimuli bind to seven transmembrane receptors on the apical surface of the cells, where they initiate a second-messenger signaling cascade, in which phosphoinositide signaling plays a critical role (Margolskee, 2002; Montmayeur and Matsunami, 2002; Medler and Kinnamon, 2004). Exposure of taste tissue to bitter and sweet tastants activates phospholipase C (PLC), leading to hydrolysis of phosphatidylinositol 4,5-bisphosphate $\left(\mathrm{PIP}_{2}\right)$ to diacylglycerol (DAG) and inositol trisphosphate $\left(\mathrm{IP}_{3}\right)$ (Hwang et al., 1990; Bernhardt et al., 1996; Spielman et al., 1996; Rossler et al., 1998; Huang et al., 1999). More direct evidence for the importance of phosphoinositide signaling in taste transduction comes from the observation that mice with a targeted deletion of the PLC $\beta 2$ gene have diminished sensitivity to bitter, sweet, and umami tastants (Zhang et al., 2003; Dotson et al., 2005). The transient receptor potential M5 (TRPM5) ion channel, which is specifically expressed in taste cells (Perez et al., 2002), is critical for this signaling cascade, and mice with a targeted deletion of

Received Nov. 15, 2006; revised April 18, 2007; accepted April 19, 2007.

This work was supported by National Institute on Deafness and Other Communication Disorders Grants 004564 (E.L.) and 003155 (R.M.). We thank S. Kinnamon, N. Chaudhari, D. Liu, and Y. Wang for help with taste cell isolation; D. Arnold, D. McKemy, and R. Chow for helpful discussions; and H. Waters for expert technical support.

Correspondence should be addressed to Emily R. Liman, Program in Neurosciences, University of Southern California, 3641 Watt Way, Los Angeles, CA 90089. E-mail: liman@usc.edu.

D0I:10.1523/JNEUROSCI.4973-06.2007

Copyright $\odot 2007$ Society for Neuroscience $\quad$ 0270-6474/07/275777-10\$15.00/0
TRPM5 have little or no ability to detect physiologically relevant concentrations of bitter or sweet substances (Zhang et al., 2003; Damak et al., 2006). Thus, it can be hypothesized that taste transduction involves a PLC signaling cascade that leads to activation of the TRPM5 ion channel, a signaling pathway that is similar, in many respects, to phototransduction in the fly eye (Montell and Rubin, 1989; Ranganathan et al., 1995; Hardie and Raghu, 2001).

How does PLC signaling regulate the activity of TRPM5 ion channels? This question has been addressed by studying the properties of cloned TRPM5 channels expressed in heterologous cells type with contradictory results. In particular, although one study showed that activation of rat TRPM5 channels was independent of an elevation of intracellular $\mathrm{IP}_{3}$ or the ensuing rise in intracellular $\mathrm{Ca}^{2+}$ (Zhang et al., 2003), other studies showed that mouse TRPM5 channels could be directly activated by intracellular $\mathrm{Ca}^{2+}$ (Hofmann et al., 2003; Liu and Liman, 2003; Prawitt et al., 2003) or by $\mathrm{Ca}^{2+}$ store depletion (Perez et al., 2002). To add to the uncertainty concerning the mechanism by which TRPM5 channels are activated, it is likely that heterologously expressed channels do not fully recapitulate the properties of native channels, which may be composed of multiple subunits (Chen et al., 1993).

To directly determine the mechanism by which native TRPM5 channels are activated, we measured ionic currents in taste receptor cells from genetically modified mice, in which TRPM5dependent currents could be unequivocally identified. Our results show that native TRPM5 channels are directly activated by intracellular $\mathrm{Ca}^{2+}$, downstream of $\mathrm{IP}_{3}$-mediated release of $\mathrm{Ca}^{2+}$ from intracellular stores. 


\section{Materials and Methods}

Transgenic mice. Transgenic mice in which $11 \mathrm{~kb}$ of mouse Trpm5 5' flanking sequence drives expression of enhanced green fluorescent protein (eGFP) (TRPM5-GFP) and mice carrying a targeted deletion of the TRPM5 gene (TRPM5 ${ }^{-/-}$) were described previously (Clapp et al., 2006; Damak et al., 2006). The two strains of mice were mated to generate animals that were positive for the GFP reporter and were $+/+,+/-$, or $-1-$ for TRPM5 expression. Animals were genotyped as described previously (Clapp et al., 2006; Damak et al., 2006). Additional TRPM5 ${ }^{+/+}$ animals were generated by crossing these animals with wild-type mice of the B6D2 strain (Harlan, Indianapolis, IN).

Antibody generation and immunostaining of taste tissue. The terminal 70 amino acids of mouse TRPM5 (amino acids 1088-1158) were fused to glutathione $S$-transferase using the vector pGEX4T1 (Pfizer, New York, NY). Fusion protein was purified over glutathione Sepharose 4B, analyzed by PAGE, and used to inoculate two rabbits (Strategic Biosolutions, Newark, DE). Unpurified polyclonal antibody was used at a dilution of 1:500. Taste tissue was harvested according to approved methods by the University of Southern California Institutional Animal Care and Use Committee. Sectioning and staining of frozen tissue sections was as described previously (Liman et al., 1999). Images were acquired with Zeiss (Oberkochen, Germany) 510 Meta confocal microscope.

Acute dissociation of taste receptor cells. Mouse taste cells were prepared using a modification of published methods (Spielman et al., 1989; Behe et al., 1990). In brief, we injected an enzyme cocktail (collagenase, $2 \mathrm{mg} / \mathrm{ml}$; dispase, $5 \mathrm{mg} / \mathrm{ml}$; Roche, Indianapolis, IN) between the epithelium and muscle layers of the tongue and allowed the tissue to incubate for $20 \mathrm{~min}$ in Tyrode's solution bubbled with 95\% oxygen. After this treatment, the epithelium was peeled off and washed with Tyrode's solution, and a piece of tissue containing circumvallate papillae was isolated. This tissue was washed with dichlorofluorescein (DCF) (divalent-free solution) and incubated with DCF containing Pronase ( $1.5 \mathrm{mg} / \mathrm{ml}$; Sigma, St. Louis, MO) and elastase $(1 \mathrm{mg} / \mathrm{ml}$; Worthington, Lakewood, NJ) for $20 \mathrm{~min}$. The tissue was then washed with Tyrode's solution, triturated with a firepolished Pasteur pipette, and plated onto a glass coverslip. GFP-positive $\left(\mathrm{GFP}^{+}\right)$taste receptor cells were identified under epifluorescence and were used within $5 \mathrm{~h}$ of plating. Tyrode's solution contained the following (in mM): $145 \mathrm{NaCl}, 5 \mathrm{KCl}, 1 \mathrm{MgCl}_{2}, 2 \mathrm{CaCl}_{2}, 20$ dextrose, 10 HEPES, and 1 pyruvate, $\mathrm{pH}$ 7.4. DCF contained the following (in $\mathrm{mm}$ ): $65 \mathrm{NaCl}$, $26 \mathrm{NaHCO}_{3}, 20 \mathrm{KCl}, 20$ D-glucose, $2.5 \mathrm{NaH}_{2} \mathrm{PO}_{4}, 1$ EDTA, and 1 pyruvate, $\mathrm{pH}$ 7.4.

Tissue culture and transfection of human embryonic kidney cells. TRPM5 fused to eGFP (Liu and Liman, 2003) or enhanced cyan fluorescent protein (CFP) (Rizzo et al., 2004) was transiently transfected into cells human embryonic kidney 293 (HEK-293) by using Fugene (Roche Molecular Biochemicals, Indianapolis, IN) as suggested by the manufacturer. Transfected cells were identified under epifluorescence. Recordings were performed $24-72 \mathrm{~h}$ after transfection at room temperature.

Electrophysiology. Patch pipettes were fabricated from borosilicate glass and fire polished to a resistance of 2-3 $\mathrm{M} \Omega$. Only recordings in which a gigaohm seal was achieved were used in the analysis. Excised patch recording was performed as described previously (Liu and Liman, 2003). Briefly, after formation of a gigaohm seal, the patch was excised into $\mathrm{Ca}^{2+}$-free solution and rapidly moved in front of a linear array of microcapillary tubes (Warner Instruments, Hamden, CT). For all experiments, the membrane potential was held at $-80 \mathrm{mV}$. All recording were made with an Axopatch 200B amplifier, digitized with a Digidata 1322a, acquired with pClamp 8.2, and analyzed with Clampfit 8.2 (Molecular Devices, Palo Alto, CA). Records were sampled at $5 \mathrm{kHz}$ and filtered at 1 $\mathrm{kHz}$. Representative data shown in the figures was in some cases decimated 10- or 20-fold before exporting into the graphics programs Origin (Microcal, Northampton, MA) and Coreldraw (Corel, Eden Prairie, $\mathrm{MN})$ to reduce the size of the files.

Solutions. For whole-cell recording, the bath solution was as follows (in mM): $125 \mathrm{NaCl}, 25 \mathrm{NaHCO}_{3}, 25$ glucose, $2.5 \mathrm{KCl}, 1.25 \mathrm{NaH}_{2} \mathrm{PO}_{4}, 2$ $\mathrm{CaCl}_{2}$, and $1 \mathrm{MgCl}_{2}$ (bubbled with $95 \% \mathrm{O}_{2}, 5 \% \mathrm{CO}_{2}$ ). Internal Cs ${ }^{+}$. based solution contained the following (in $\mathrm{mm}$ ): $111 \mathrm{CsAsp}, 22 \mathrm{CsCl}, 11$ HEPES, 2 MgATP, and $3.3 \mathrm{Na}_{2} \mathrm{ATP}$, pH 7.2. To this solution, we added the following: $2.5 \mathrm{~mm}$ 2,6-dimethyl-4-nitropyridine (DMNP)-EDTA, $0.75 \mathrm{mM} \mathrm{CaCl}_{2}$ (caged $\mathrm{Ca}^{2+}$ ) or $50 \mu \mathrm{M}$ 1-(2-nitrophenyl)ethyl (NPE)caged $\mathrm{IP}_{3}\left(\right.$ caged $\left.\mathrm{IP}_{3}\right), 10 \mu \mathrm{M}$ EGTA or $50 \mu \mathrm{M}$ NPE-caged $\mathrm{IP}_{3}$, and $5 \mathrm{~mm}$ BAPTA. Internal $\mathrm{K}^{+}$-based solution contained the following (in $\mathrm{mM}$ ): $120 \mathrm{KAsp}, 20 \mathrm{KCl}, 10 \mathrm{HEPES}, 2 \mathrm{MgATP}, 3 \mathrm{Na}_{2}$ ATP, $0.3 \mathrm{GTP}, 2.5$ DMNPEDTA, and $0.75 \mathrm{CaCl}_{2}, \mathrm{pH}$ 7.2. DMNP-EDTA, and NPE-caged $\mathrm{IP}_{3}$ were from Invitrogen (Carlsbad, CA).

For excised patch recording, the pipette solution contained the following (in mM): $150 \mathrm{NaCl}, 10$ HEPES, and $2 \mathrm{CaCl}_{2}, \mathrm{pH}$ 7.4. $\mathrm{Ca}^{2+}$-free solution contained the following (in $\mathrm{mM}$ ): $150 \mathrm{NaCl}, 10$ HEPES, and 2 HEDTA, pH 7.4. Cytosolic solutions with micromolar concentrations of free $\mathrm{Ca}^{2+}$ were obtained by adding $\mathrm{Ca}^{2+}(1.1,1.5$, or $1.9 \mathrm{~mm})$ to obtain free $\mathrm{Ca}^{2+}$ concentrations of 5,12 , and $50 \mu \mathrm{M}$, respectively. Solutions containing $200 \mu \mathrm{M}$ to $1 \mathrm{~mm}$ free $\mathrm{Ca}^{2+}$ were made by adding the appropriate amount of $\mathrm{CaCl}_{2}$ to a solution containing $150 \mathrm{~mm} \mathrm{NaCl}$ and $10 \mathrm{mM}$ HEPES, pH 7.4 with $\mathrm{NaOH}$. For ATP blocking experiments, we added $100 \mu \mathrm{M} \mathrm{Na}{ }_{2}$ ATP to the solution containing $1 \mathrm{mM} \mathrm{Ca}^{2+}$; this is expected to yield a final concentration of $18 \mu \mathrm{M}$ free ATP and $918 \mu \mathrm{M}$ free $\mathrm{Ca}^{2+}$. All $\mathrm{Ca}^{2+}$ concentrations are reported as calculated with MaxChelator (www. stanford.edu/ $\sim$ cpatton/maxc.html) and were confirmed by direct measurement with a $\mathrm{Ca}^{2+}$-sensitive electroprobe (Microelectrodes, Bedford, $\mathrm{NH})$. For some experiments, we added the following biochemicals to the $\mathrm{Ca}^{2+}$-free solution: diC8-PIP 2 (Echelon Bioscience, Salt Lake City, UT), 1,2-dioctanoyl-sn-glycerol (DOG), phosphatidic acid (PA) (Avanti Polar Lipids, Alabaster, $\mathrm{AL}$ ), and $\mathrm{IP}_{3}$ (Invitrogen).

Flash photolysis of caged compounds. All experiments were performed on an Olympus Optical (Tokyo, Japan) IX71 microscope. For most experiments, light from a xenon arc lamp was passed through a bandpass filter (380xv1; Chroma Technology, San Diego, CA) that was part of an LEP filter wheel/shutter (Ludl, Hawthorne, NY) operated under computer control (Simple PCI; Compix, Sewickley, PA). The shutter was opened for $2 \mathrm{~s}$ to uncage $\mathrm{Ca}^{2+}$ or $4 \mathrm{~s}$ to uncage $\mathrm{IP}_{3}$. For some experiments [e.g., uncaging $\mathrm{Ca}^{2+}$ using a $\mathrm{K}^{+}$-based intracellular solution (see Fig. $4 C, D)$ ], a uniblitz shutter (Vincent Associates, Rochester, NY) controlled light from a mercury arc lamp that was then passed through a $350 / 50 \times$ bandpass filter (Chroma Technology, San Diego, CA). The shutter was opened for $1 \mathrm{~s}$ to uncage $\mathrm{Ca}^{2+}$. To allow uniform dialysis of the cell with the caged compounds, we waited for $40 \mathrm{~s}$ after breaking into whole-cell recording mode before opening the shutter. Under these conditions, multiple responses could usually be obtained from the same cell. For analysis, only the first response from each cell was used, and the evoked current was measured as the difference between the peak current in response to the UV flash and the resting current before stimulation.

$\mathrm{Ca}^{2+}$ imaging. $\mathrm{Ca}^{2+}$ imaging was performed on an Olympus Optical IX71 microscope equipped with an LEP filter wheel (Ludl Electronic Products) and ORCA ER camera (Hamamatsu Photonics, Shizuoka, Japan). Cells transfected with TRPM5 fused to CFP were loaded through the patch pipette with the low-affinity $\mathrm{Ca}^{2+}$ indicator Fluo-5F $(20 \mu \mathrm{M})$. The fluorescence emission from Fluo- $5 \mathrm{~F}$ was detected using a yellow GFP filter set (Chroma Technology, Rockingham, VT). Images were captured and analyzed with simple PCI (Compix).

\section{Results}

\section{TRPM5-dependent currents in taste receptor cells are} activated by elevation of intracellular $\mathrm{IP}_{3}$

To understand the mechanism by which TRPM 5 currents in taste receptors cells are activated, we used genetically modified mice in which these currents could be unequivocally identified. In one mouse strain, GFP expression was driven by the TRPM5 promoter (Clapp et al., 2006), allowing us to visually identify cells that have the capacity to transcribe the native TRPM5 gene. This strain was crossed to mice that carried a targeted deletion of the TRPM5 gene to generate mice that were $+/+,+/-$, or $-/-$ for TRPM5 channel expression. To confirm fidelity of the GFP marker for TRPM5-expressing cells, we stained sections of the tongue containing circumvallate papillae with a polyclonal antibody directed against mTRPM5. In TRPM5 $5^{+/+}$and TRPM5 $5^{+/-}$ mice, all GFP-positive cells showed TRPM5 immunoreactivity 

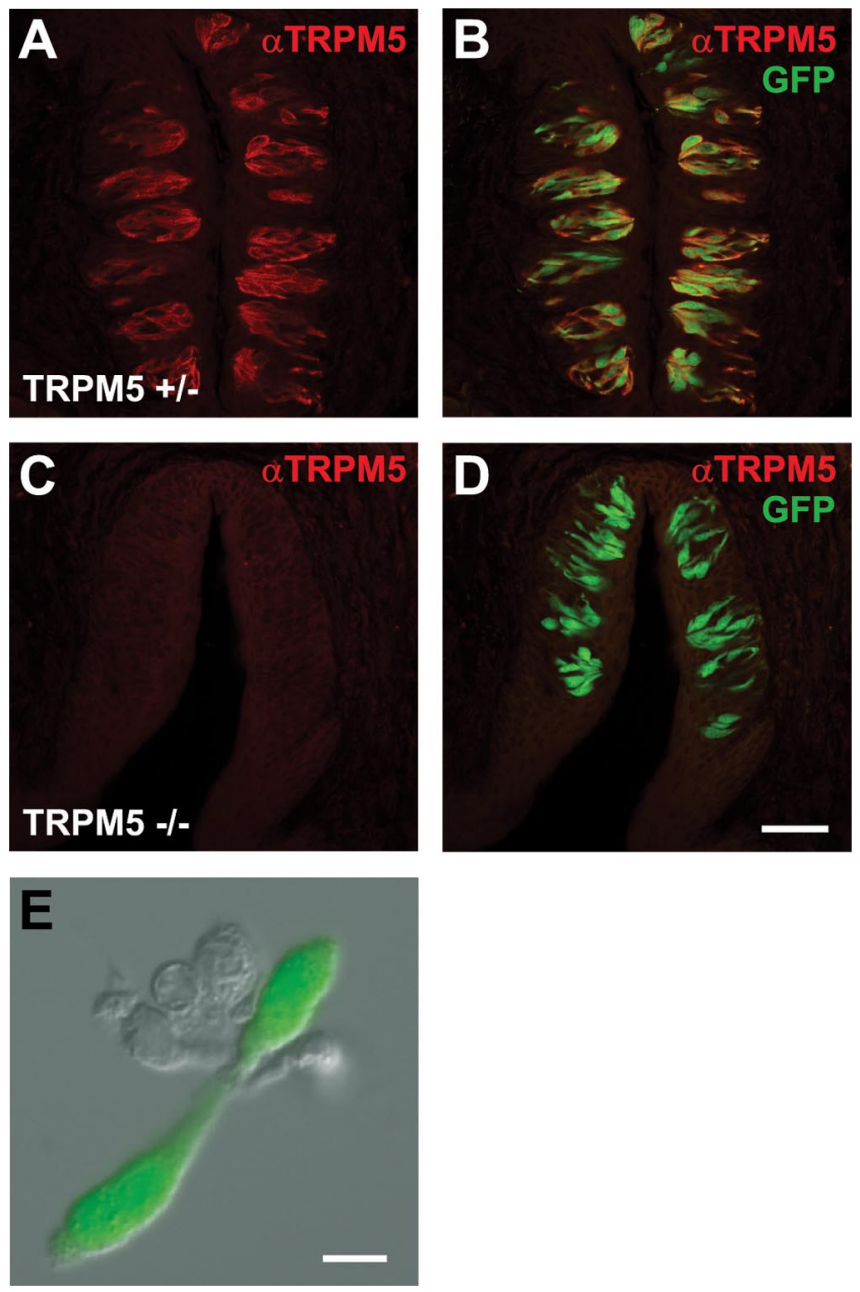

Figure 1. TRPM5 is expressed in GFP-positive taste cells in transgenic TRPM5-GFP mice. A, A section of circumvallate papillae from a transgenic mouse in which the TRPM5 promoter drives expression of GFP stained with an antibody against TRPM5 (red). Note that this mouse was RRPM $^{+/-} \cdot \boldsymbol{B}$, The same section showing complete coincidence between GFP fluorescence (green) and TRPM5 immunoreactivity (red). C, D, A section of circumvallate papillae from a TRPM5 $^{-/-}$mouse stained with an antibody against TRPM5 shows normal GFP expression (green) and complete absence of TRPM5 immunoreactivity (red), as expected. $\boldsymbol{E}$, Isolated taste receptor cells from a mouse in which the TRPM5 5 promoter drives expression of GFP show intense green fluorescence. These cells are typical of those used for patch-clamp recording in this paper. Scale bars: (in $\boldsymbol{D}) \mathbf{A}-\boldsymbol{D}, 50 \mu \mathrm{m} ; \boldsymbol{E}, 10 \mu \mathrm{m}$.

(Fig. 1 $A, B$ ), whereas no TRPM5 immunostaining was observed in sections from TRPM5 $5^{-/-}$mice (Fig. $1 C, D$ ). Thus, GFP expression can be used to identify TRPM5-expressing cells or those that would have made TRPM5 had the gene not been deleted. Note that all mice studied were heterozygotic or homozygotic for expression of the GFP transgene, and no attempt was made to discriminate further between these two genotypes.

In acutely dissociated taste cells, bright GFP fluorescence was observed in $\sim 30 \%$ of morphologically identifiable taste receptor cells, consistent with the proportion of cells expected to express TRPM5 (Fig. 1E) (Perez et al., 2002). Whole-cell patch-clamp recording from these cells showed that they have voltage-gated sodium currents as expected (Akabas et al., 1988) (data not shown).

To determine whether native TRPM5 currents can be activated downstream of an elevation of $\mathrm{IP}_{3}$, we initially conducted experiments in which $\mathrm{IP}_{3}$, dissolved in a $\mathrm{Cs}^{+}$-based intracellular solution was dialyzed into taste cells. However, the presence of a

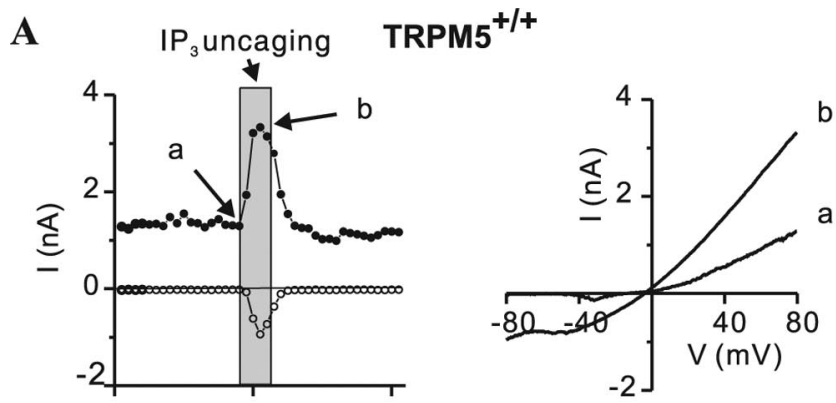

B TRPM $^{-1-}$
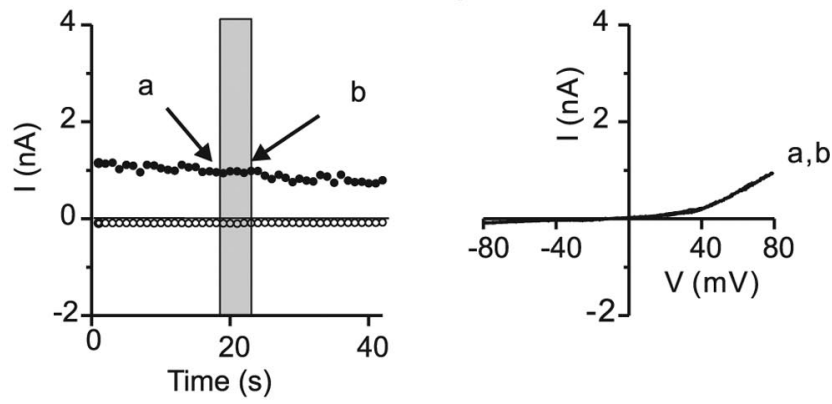

C

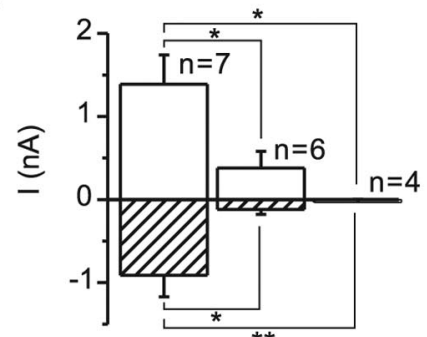

TRPM5

BAPTA

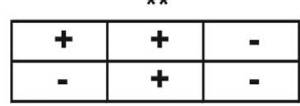

Figure 2. Activation of a TRPM5-dependent current in taste receptors cells by elevation of intracellular $\mathrm{IP}_{3}$. $A$, Current activation in response to flash photolysis of caged $\mathrm{IP}_{3}$ in a TRPM5expressing taste receptor cell $\left(\mathrm{GFP}^{+}\right)$from a $\mathrm{TRPM}^{+/+}$mouse. Time course of the current at $+80 \mathrm{mV}$ (filled circles) and $-80 \mathrm{mV}$ (open circles). The opening of the shutter on the UV lamp is indicated with the gray bar. Right shows the current-voltage relationship obtained from ramp depolarizations (1 V/s) before the flash (a) and at the peak of the response (b). $\boldsymbol{B}$, № current was activated in a $\mathrm{TRPM}^{-/-}$taste receptor cell in response to flash photolysis of caged $\mathbb{I}_{3}$. $\boldsymbol{C}$, Mean data from experiments such as those in $\boldsymbol{A}$ and $\boldsymbol{B}$. Response amplitude was measured as the difference in the current after and before uncaging $I P_{3}$. Note that inclusion of BAPTA $(5 \mathrm{~mm})$ severely attenuated the response to uncaging $\mathrm{IP}_{3}$ in $T R P M 5^{+/+}$taste cells. Data are represented by the mean \pm SEM. ${ }^{*} p<0.05,{ }^{* *} p<0.01$, Student's $t$ test.

relatively large outwardly rectifying current in the absence of $\mathrm{IP}_{3}$ in taste cells from both TRPM5 $5^{+/+}$and TRPM5 $5^{-/-}$animals complicated analysis of the results (Fig. $2 A, B$ and data not shown). We therefore, instead, perfused cells with an inactive form of $\mathrm{IP}_{3}$ $\left(\mathrm{NPE}\right.$-caged $\mathrm{IP}_{3}$ ) that could be activated by exposure to light of $380 \mathrm{~nm}$. In response to release of caged $\mathrm{IP}_{3}$, a large current was evoked in taste cells from TRPM5 $5^{+/+}$animals (Fig. $2 A, C$ ). The evoked current had a reversal potential of $2.4 \pm 2.9 \mathrm{mV}(n=7)$, indicating that it was nonselective among $\mathrm{Na}^{+}$and $\mathrm{Cs}^{+}$, and it decayed with a time course that could be fit with a single exponential ( $\tau$ of $2-7 \mathrm{~s})$. No current was elicited by the same protocol in TRPM5 ${ }^{-/-}$animals (Fig. $2 B$ ). A voltage-activated $\mathrm{Na}^{+}$current was evident in most cells, and this served as a convenient indicator that the cells were healthy and that good electrical access in whole-cell recording mode had been achieved (Akabas et 
A

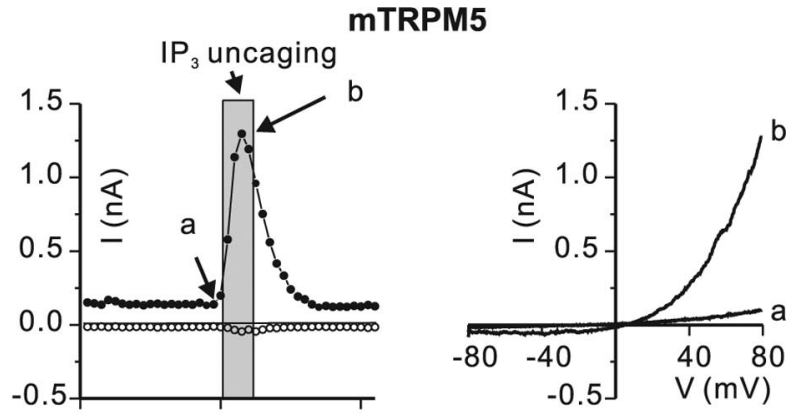

B
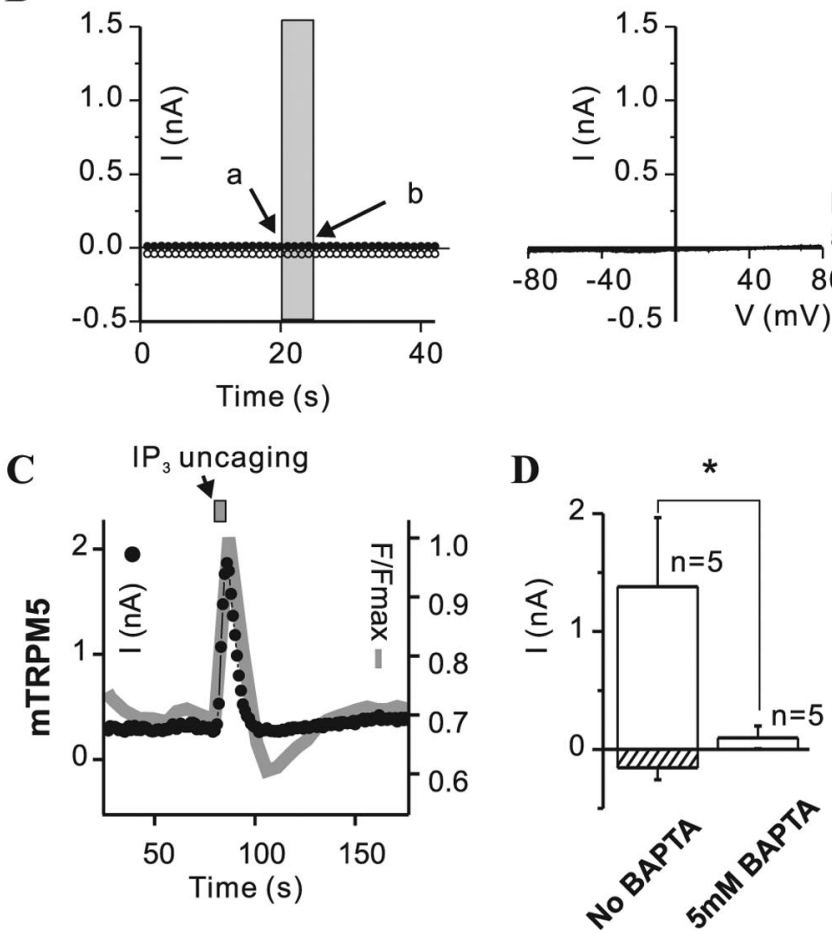

Figure 3. Activation of heterologously expressed TRPM5 channels by elevation of intracelIular $\mathrm{IP}_{3}$. A, B , Currents activated by flash photolysis of caged IP in HEK-293 cells transfected with mTRPM5 $(\boldsymbol{A})$ or in untransfected HEK-293 cells $(\boldsymbol{B})$. Filled and open circles represent the currents at +80 and $-80 \mathrm{mV}$, respectively. Gray bar shows the time during which the shutter on the UV light source was open. Right panels show the current-voltage relationship obtained from ramp depolarizations $(1 \mathrm{~V} / \mathrm{s}$ ) before the flash (a) and at the peak of the response (b). Similar results were obtained in five cells for each condition. C, Simultaneous measurement of the magnitude of the current (left axis; filled circles) and the change in intracellular $\mathrm{Ca}^{2+}$ (right axis; gray line) in response to uncaging $\mathbb{I P}_{3}$ in a HEK-293 cell transfected with mTRPM5. The $\mathrm{Ca}^{2+}$ indicator Fluo-5F $(10 \mu \mathrm{m})$ was loaded through the patch pipette. Similar results were obtained in five cells. $\boldsymbol{D}$, Mean magnitude of the response to uncaging $\mathbb{I P}_{3}$ in HEK-293 cells transfected with $\mathrm{mTRPM} 5$ in the presence and absence of $5 \mathrm{~mm}$ BAPTA $\left(V_{\mathrm{m}}\right.$ of $\left.+80 \mathrm{mV}\right)$. Data are represented by the mean \pm SEM. ${ }^{*} p<0.05$, Student's $t$ test.

al., 1988). Thus, we can conclude that the current observed in TRPM $^{+/+}$cells during uncaging IP $_{3}$ depends on TRPM5 expression and most likely represents the native TRPM5 current. To confirm that, under the conditions of our experiments, flash photolyis of caged $\mathrm{IP}_{3}$ had the expected effect of releasing $\mathrm{Ca}^{2+}$ from intracellular stores and activating heterologously expressed TRPM5 channels, we recorded from HEK-293 cells transfected with mTRPM5. Flash photolysis of caged $\mathrm{IP}_{3}$ activated a large outwardly rectifying current in HEK-293 cells expressing TRPM5 $(n=5)$ but not in untransfected cells $(n=5)$ (Fig. $3 A, B)$, and it caused a transient elevation of intracellular $\mathrm{Ca}^{2+}$, as determined by measuring fluorescent emission from the $\mathrm{Ca}^{2+}$ indicator Fluo-5F $(n=5)$ (Fig. 3C).

$\mathrm{IP}_{3}$ might act directly on TRPM5 channels or it could act indirectly by releasing intracellular $\mathrm{Ca}^{2+}$, which could be the stimulus that gates TRPM5 channels. This latter hypothesis predicts that the response to elevation of $\mathrm{IP}_{3}$ should be blocked by heavy buffering of intracellular $\mathrm{Ca}^{2+}$. In support of this possibility, we found that, in TRPM5-expressing taste cells $(n=6)$ (Fig. $2 C)$ and in HEK-293 cells expressing TRPM5 $(n=5)$ (Fig. $3 D)$, responses to uncaging $\mathrm{IP}_{3}$ in the presence of $5 \mathrm{~mm}$ BAPTA were severely attenuated compared with the responses measured when a low concentration of $\mathrm{Ca}^{2+}$ buffer was included in the pipette solution (10 $\mu \mathrm{M}$ EGTA).

\section{Intracellular $\mathrm{Ca}^{2+}$ activates TRPM5-dependent currents in taste cells}

To determine whether a rise in intracellular $\mathrm{Ca}^{2+}$ is sufficient to activate TRPM5-dependent currents in taste cells, we introduced DMNP-EDTA (caged $\mathrm{Ca}^{2+}$ ) in whole-cell patch-clamp recording mode and measured the electrical response when $\mathrm{Ca}^{2+}$ was released by flash photolysis. In TRPM5-expressing taste cells, flash photolysis of caged $\mathrm{Ca}^{2+}$ consistently activated a large current (Fig. $4 A, C$ ). With an intracellular solution that contained $\mathrm{Cs}^{+}$and an external solution in which $\mathrm{Na}^{+}$was the principle cation, this evoked current reversed at $5.5 \pm 2.9 \mathrm{mV}(n=8)$ (Fig. $4 \mathrm{~A}$ ), consistent with nonselective permeability for $\mathrm{Cs}^{+}$compared with $\mathrm{Na}^{+}$(see below). After activation, the current decayed with a variable time course (the time constant of decay ranged from $<1$ to $60 \mathrm{~s}$ ). In contrast, in taste cells from TRPM5 ${ }^{-/-}$ animals, no current was evoked by uncaging $\mathrm{Ca}^{2+}$ (Fig. $4 B, C$ ). In HEK-293 cells transfected with mTRPM5, flash photolysis of caged $\mathrm{Ca}^{2+}$ led to a transient activation of a large current (Fig. $5 A, C$ ) and more prolonged elevation of intracellular $\mathrm{Ca}^{2+}$ (Fig. 5C). The current evoked in HEK-293 cells expressing mTRPM5 was somewhat more rectifying than that evoked in taste cells $\left(I_{+80}\right.$ $\mathrm{mV} / I_{-80 \mathrm{mV}}$ was $3.9 \pm 1.3$ in HEK-293 cells, $n=5$ and $1.9 \pm 0.2 \mathrm{in}$ taste cells, $n=8 ; p=0.05$, two-tailed $t$ test). No current was elicited by uncaging $\mathrm{Ca}^{2+}$ in untransfected HEK-293 cells (Fig. $5 B)$.

To determine whether TRPM5 currents could be activated under more physiological conditions, we dialyzed taste receptor cells with an internal solution in which $\mathrm{K}^{+}$was the principal cation. Flash photolysis of caged $\mathrm{Ca}^{2+}$ elicited a current in cells from TRPM5 $5^{+/+}$animals $(n=6)$, but not in cells from TRPM5 $5^{-/-}$animals $(n=5)$, indicating that the evoked current can be attributed entirely to the gating of TRPM5 channels (Fig. $4 C$ ). With $\mathrm{Na}^{+}$as the principal cation in the external solution, the current reversed at $3.3 \pm 4.8 \mathrm{mV}(n=6)$, indicating that the channels are equally permeable to $\mathrm{Na}^{+}$and $\mathrm{K}^{+}$(Fig. 4D). When the bath solution was exchanged for a solution containing $50 \mathrm{mM}$ $\mathrm{Ca}^{2+}$ [80 mM N-methyl-D-glucamine (NMDG)], the reversal potential of the evoked current was shifted to $-61.4 \pm 3.8(n=6)$ $\mathrm{mV}$, indicating that the channels have little or no permeability to $\mathrm{Ca}^{2+}\left(P_{\mathrm{Ca}^{2+}} / P_{\mathrm{K}^{+}}<0.05\right)$ (Fig. $\left.4 D\right)$.

Native TRPM5 channels are $\mathrm{Ca}^{2+}$-activated, voltagemodulated cation channels

We recorded from inside-out membrane patches to determine whether $\mathrm{Ca}^{2+}, \mathrm{IP}_{3}$, or other potential second messengers could act directly at the plasma membrane to gate TRPM5 channels in taste receptor cells. In GFP-expressing cells from $T R P M 5^{+/+}$animals, $\mathrm{Ca}^{2+}(50$ or $100 \mu \mathrm{M})$ activated an inward current of $>10$ $\mathrm{pA}$ at $-80 \mathrm{mV}$ in 19 of 22 patches (Fig. 6). The magnitude of the 

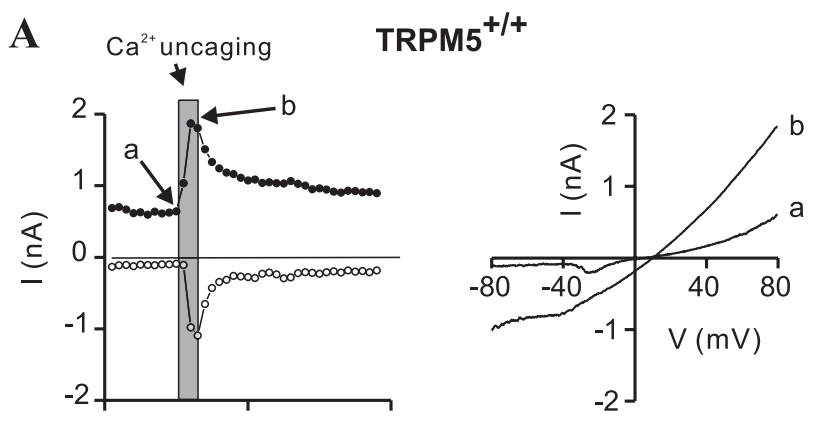

B

TRPM5 ${ }^{-1-}$

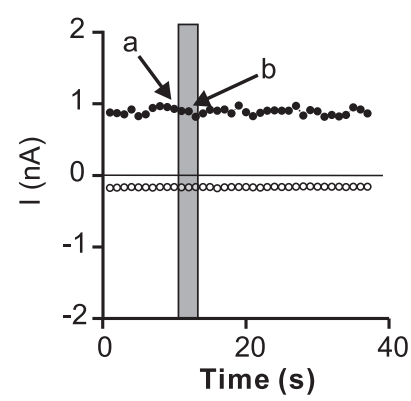

C

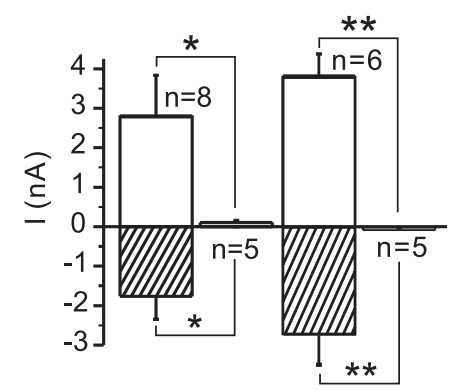

D
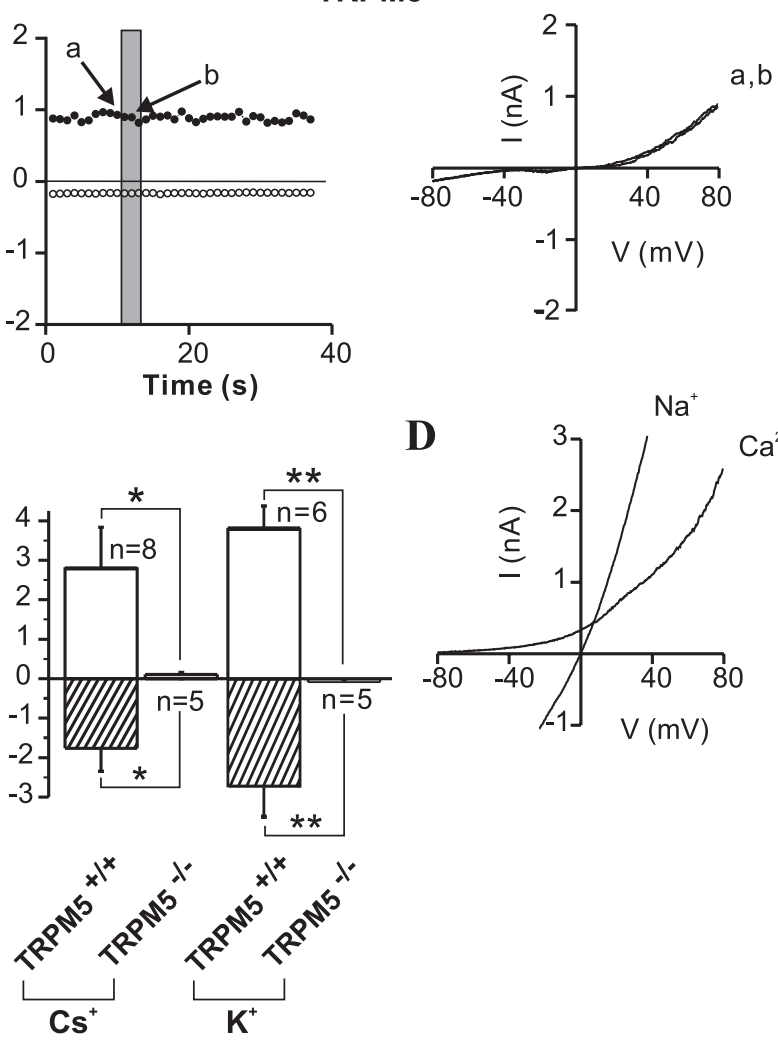

Figure 4. Activation of TRPM5-dependent currents in taste receptor cells by flash photolysis of caged $\mathrm{Ca}^{2+} . \boldsymbol{A}, \boldsymbol{B}$, Current activated in response to flash photolysis of caged $\mathrm{Ca}^{2+}$ in a taste receptor cell from a $T R P M 5^{+/+}$mouse $(\boldsymbol{A})$ and a $T R P M 5^{-/-}$mouse $(\boldsymbol{B})$. The patch pipette contained a $\mathrm{Cs}^{+}$-based solution that was supplemented with DMNP-EDTA. Time course, shown on left, of the current at $+80 \mathrm{mV}$ (filled circles) and $-80 \mathrm{mV}$ (open circles). Gray bar shows the time during which the shutter on the UV lamp was open (2.4 s). The right panels show the current-voltage relationship before the flash (a) and at the peak of the response (b). C, Mean response to uncaging $\mathrm{Ca}^{2+}$ in taste cells from $\mathrm{TRPM}^{+/+}$and $\mathrm{TRPM}^{-/-}$mice. The internal solution contained either $\mathrm{Cs}^{+}$or $\mathrm{K}^{+}$, as indicated on the graph. Response amplitude was measured as the difference in the current after and before uncaging $\mathrm{Ca}^{2+} . \boldsymbol{D}$, The currentvoltage relationship of the current evoked in response to uncaging $\mathrm{Ca}^{2+}$ in a TRPM5 ${ }^{+/+}$taste cell dialyzed with an internal solution in which the principle cation was $\mathrm{K}^{+}(140 \mathrm{~mm})$. The external solution was exchanged from one in which $\mathrm{Na}^{+}$was the principal cation to one in which the principal cations were $\mathrm{Ca}^{2+}(50 \mathrm{~mm})$ and NMDG $(80 \mathrm{~mm})$. The resting current before uncaging was subtracted. Data are represented by the mean \pm SEM. ${ }^{*} p<0.05{ }^{* *} p<0.01$, Student's $t$ test.

inward currents was variable and, in one patch, was as large as 2 nA. Similarly, 15 of 16 patches from TRPM5 ${ }^{+/-}$animals responded to $\mathrm{Ca}^{2+}(50 \mu \mathrm{M})$ (range up to $1.3 \mathrm{nA}$ ). In contrast, no response was elicited by exposure to other putative second messengers, including $\mathrm{IP}_{3}$, DOG (a synthetic analog of DAG), PA, or $\mathrm{PIP}_{2}$ (Fig. 6A,C). To confirm that this $\mathrm{Ca}^{2+}$-activated current

\section{A mTRPM5}
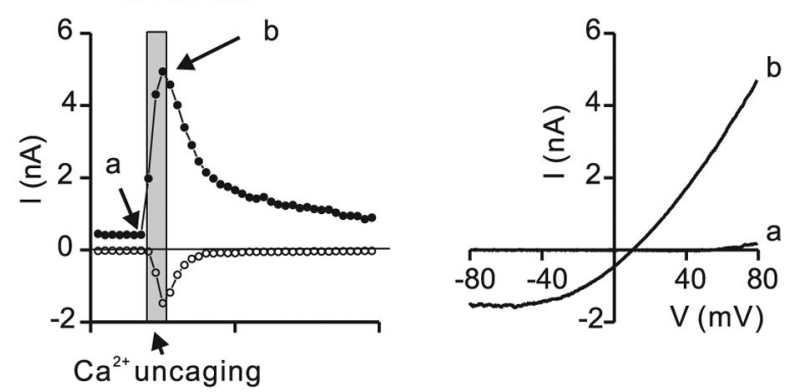

B
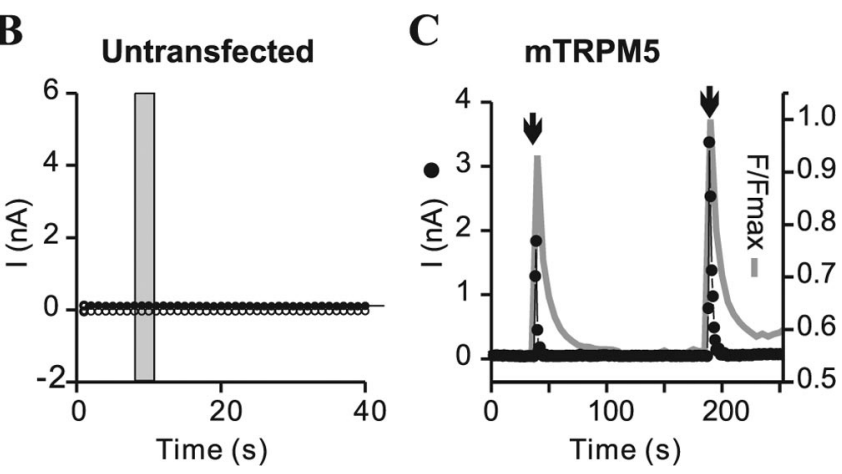

Figure 5. Activation of cloned TRPM5 channels by elevation of intracellular $\mathrm{Ca}^{2+} . \boldsymbol{A}, \boldsymbol{B}$, Current activated in response to flash photolysis of caged $\mathrm{Ca}^{2+}$ in HEK-293 cells transfected with mTRPM5 $(\boldsymbol{A})$ or in untransfected HEK-293 cells $(\boldsymbol{B})$. Filled and open circles represent the currents at +80 and $-80 \mathrm{mV}$, respectively. Gray bar shows the time during which the shutter on the UV light source was open. Current-voltage relationship of the response in the transfected cell before the flash (a) and at the peak of the response (b) is shown on the right. $C$, Simultaneous measurement of the current at $+80 \mathrm{mV}$ (left axis; filled circles) and the change in intracellular $\mathrm{Ca}^{2+}$ (right axis) in HEK-293 cells transfected with mTRPM5-CFP in response to uncaging $\mathrm{Ca}^{2+}$ (indicated by the arrows). The $\mathrm{Ca}^{2+}$ indicator Fluo-5F (20 $\mu \mathrm{m}$ ) was loaded through the pipette. Note that the current decayed faster than the $\mathrm{Ca}^{2+}$ signal and that multiple responses could be evoked in the same cell.

represented the native TRPM5 conductance, we recorded from patches excised from $\mathrm{GFP}^{+}$taste receptor cells from TRPM5 $5^{-/-}$ mice. An inward current in response to $50 \mu \mathrm{M} \mathrm{Ca}^{2+}$ was observed in only 5 of 25 patches (range up to $100 \mathrm{pA}$ ) (Fig. 6B,D), and these small responses were later found to represent a conductance that was clearly distinct from that of TRPM5 (see Figs. $8 E$, 9). The severe attenuation in the magnitude of the $\mathrm{Ca}^{2+}$-activated current in TRPM5 ${ }^{-1-}$ taste cells allows (Fig. 6D) us to conclude that the conductance activated by intracellular $\mathrm{Ca}^{2+}$ in $\mathrm{TRPM}^{+/+}$ and TRPM $5^{+/-}$taste cells primarily represents the native TRPM5 conductance.

We measured the ionic selectivity of the native TRPM5 conductance in excised patches by changing the main intracellular cation while keeping the concentration of activating $\mathrm{Ca}^{2+}$ constant. Based on changes in the reversal potential of the current, we calculated the relative permeability of $\mathrm{K}^{+}$to $\mathrm{Na}^{+}$as $P_{\mathrm{K}^{+}} / P_{\mathrm{Na}^{+}}=$ $0.91 \pm 0.13(n=3)$. The currents were relatively impermeable to the large monovalent cation $\mathrm{NMDG}^{+}\left(P_{\mathrm{NMDG}^{+}} / P_{\mathrm{Na}^{+}}=0.10 \pm\right.$ $0.04 ; n=4)$ (Fig. 7A). Thus, based on these results, in combination with the data from whole-cell recording, we conclude that the native TRPM5 conductance is equally permeable to small monovalent cations and relatively impermeable to large monovalent cations or divalent cations $\left(P_{\mathrm{Cs}^{+}}=P_{\mathrm{K}}=P_{\mathrm{Na}} \gg P_{\mathrm{NMDG}}\right.$ or $\left.P_{\mathrm{Ca}^{2+}}\right)$. In a few patches in which small numbers of channels were present, opening of single channels could be resolved (Fig. 7B). These openings showed flickery gating, as reported previously 
A
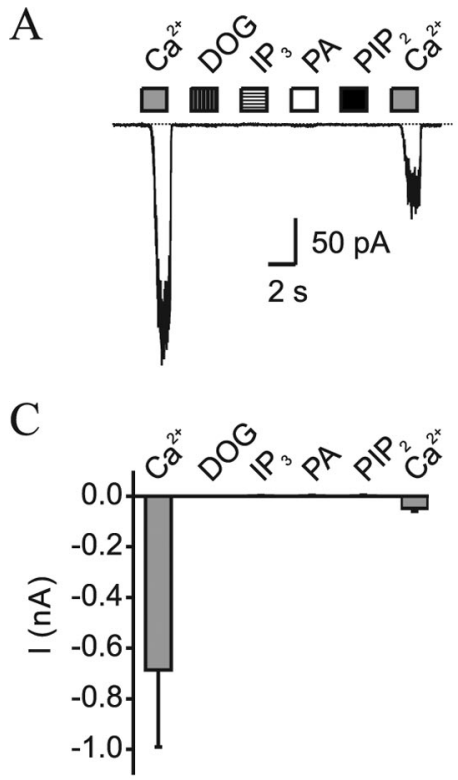

B

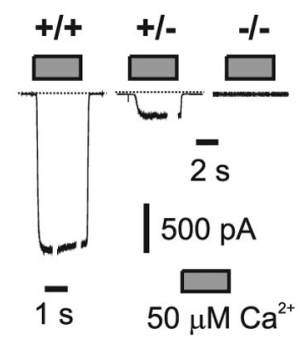

$\mathrm{D}$

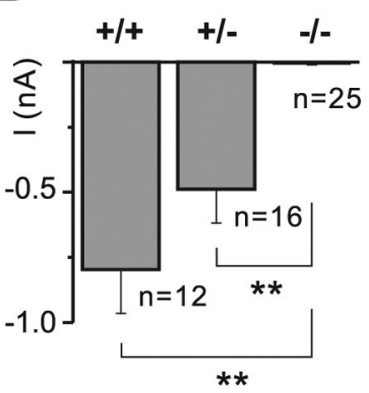

Figure 6. TRPM5-dependent channels in excised patches from taste cells are activated by intracellular $\mathrm{Ca}^{2+} . \boldsymbol{A}, \boldsymbol{C}$, Current activation in response to intracellular $\mathrm{Ca}^{2+}$, but not other potential second messengers, in an excised patch from a TRPM5 ${ }^{+/-}$taste receptor cell. Membrane potential was held at $-80 \mathrm{mV}$. Chemicals tested were as follows: $50 \mu \mathrm{M} \mathrm{Ca}{ }^{2+}, 50 \mu \mathrm{M}$ DOG, $10 \mu \mathrm{M} \mathrm{IP}, 10 \mu \mathrm{MPA}$, and $10 \mu \mathrm{M} \mathrm{PIP}_{2}$. C, Average data from experiments as in $\boldsymbol{A}(n=3)$. $\boldsymbol{B}, \boldsymbol{D}$, Currents evoked by $50 \mu \mathrm{M} \mathrm{Ca}^{2+}$ in excised patches from taste receptor cells from TRPM5 $^{+/+}$, TRPM5 $^{+/-}$, and TRPM5 ${ }^{-/-}$mice. Membrane potential was held at $-80 \mathrm{mV} . \boldsymbol{D}$, Average data from experiments as in $\boldsymbol{B}$. Data are represented by the mean \pm SEM. ${ }^{* *} p<0.01$.

for heterologously expressed TRPM5 (Liu and Liman, 2003). Amplitude histograms (supplemental Fig. 1, available at www. jneurosci.org as supplemental material) gave a unitary current size of $\sim 1.4-1.7 \mathrm{pA}$, corresponding to a conductance of 17-21 pS. Because of the fact that the channels opened only briefly, this value probably slightly underestimates the true single-channel conductance.

To determine whether native TRPM5 channels are voltage modulated, we recorded current responses to a family of voltage steps in the presence of a low concentration of intracellular $\mathrm{Ca}^{2+}$ $(5 \mu \mathrm{M})$. Currents evoked in excised patches from TRPM5 $5^{+/+}$ taste receptor cells showed a time-dependent activation after the voltage steps and a time-dependent relaxation during repolarization to $-80 \mathrm{mV}$ (Fig. 7C). Thus, endogenous TRPM5-dependent channels in taste cells are voltage modulated as are heterologously expressed TRPM5 channels (Hofmann et al., 2003; Liu and Liman, 2003).

\section{Micromolar $\mathrm{Ca}^{2+}$ sensitivity of native TRPM5 channels}

$\mathrm{Ca}^{2+}$ sensitivity of TRPM5-dependent channels in taste cells was assessed by sequentially exposing the intracellular surface of excised patches to increasing concentrations of $\mathrm{Ca}^{2+}$ (Fig. 8A-D). Dose-response curves obtained from pooled data showed that the currents in patches from TRPM5 $5^{+/+}$and TRPM5 $5^{+/-}$mice were half-activated by 8 and $14 \mu \mathrm{M} \mathrm{Ca}^{2+}$, respectively (Fig. $8 \mathrm{A-}$ $D)$. These values are somewhat lower than the half-activating concentration of $\mathrm{Ca}^{2+}$ reported for expressed TRPM5 channels under the same conditions ( $21 \mu \mathrm{M})$ (Liu and Liman, 2003). The currents were strongly outwardly rectifying when activated by a low concentration of $\mathrm{Ca}^{2+}$ (Fig. $8 A, C$ ), consistent with the observation that, when activated by $5 \mu \mathrm{M} \mathrm{Ca}^{2+}$, TRPM5-dependent channels are voltage modulated (Fig. $7 C$ ). At higher $\mathrm{Ca}^{2+}$ con-

A

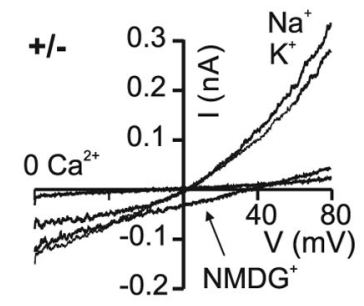

B

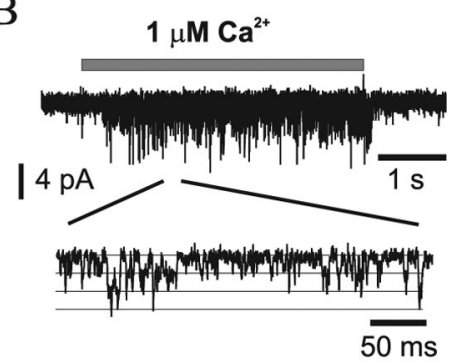

C
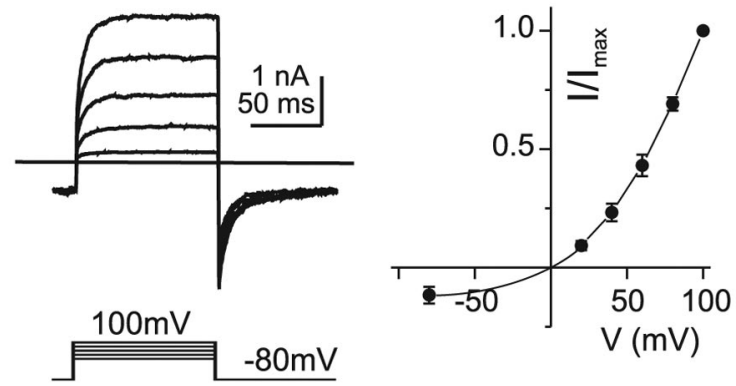

$5 \mu \mathrm{M} \mathrm{Ca}^{2+}$

Figure 7. Ion selectivity and conductance of TRPM5-dependent channels in taste cells. $A$, Ion selectivity of the $\mathrm{Ca}^{2+}$-activated current in an excised patch from a $\mathrm{TRPMS}^{+/-}$mouse. The cytoplasmic solution contained $100 \mu \mathrm{M} \mathrm{Ca}{ }^{2+}$ to activate the current. Ion selectivity was assessed by measuring the current-voltage relationship after exchanging the major cation in the cytoplasmic solution. $\mathrm{Na}^{+}$is $150 \mathrm{~mm} \mathrm{NaCl}, \mathrm{K}^{+}$is $150 \mathrm{~mm} \mathrm{KCl}, \mathrm{NMDG}$ is $125 \mathrm{~mm} \mathrm{NMDG-Cl}$ with 25 $\mathrm{mm} \mathrm{NaCl}$, and $0 \mathrm{Ca}^{2+}$ is $\mathrm{Ca}^{2+}$-free $150 \mathrm{~mm} \mathrm{NaCl}$. The holding potential was $-80 \mathrm{mV}$, and the voltage was ramped to $+80 \mathrm{mV}(1 \mathrm{~V} / \mathrm{s})$. Note the $45 \mathrm{mV}$ change in the reversal potential when the solution was changed from $\mathrm{Na}^{+}$to $\mathrm{NMDG}^{+}$and absence of a shift when the solution was changed to $\mathrm{K}^{+}$. B , Single TRPM5 channels activated by intracellular $\mathrm{Ca}^{2+}$ in an excised patch from a TRPM5 ${ }^{+/-}$animal $\left(V_{\mathrm{m}}\right.$ of $\left.-80 \mathrm{mV}\right)$. Note the flickery nature of the activity and small current amplitude of the open channels. C, Currents recorded in response to a voltage family in a patch from a $T_{R P M 5^{+/+}}$animal. Leak currents recorded before applying intracellular $\mathrm{Ca}^{2+}$ were subtracted. Right shows the steady-state current-voltage relationship, determined from experiments as in the left, normalized to the current at $+100 \mathrm{mV}$. Filled symbols represent the mean, and error bars represent the SEM $(n=5)$. For $\boldsymbol{B}$ and $\boldsymbol{C}$, the main cation in the cytoplasmic solution was $\mathrm{Na}^{+}$.

centrations, the currents became more linear, indicating that there is an interaction between $\mathrm{Ca}^{2+}$ and voltage activation of the channels (Nilius et al., 2005).

Heterologously expressed TRPM5 channels desensitize in response to prolonged $\mathrm{Ca}^{2+}$ exposure (Liu and Liman, 2003). Similarly, we observed a decline in the maximal amplitude and a change in the $\mathrm{Ca}^{2+}$ sensitivity of native TRPM5 currents after prolonged exposure to intracellular $\mathrm{Ca}^{2+}$ (Fig. $8 A-D$ ).

\section{A TRPM5-independent $\mathrm{Ca}^{2+}$-activated nonselective cation} channel in mouse taste receptor cells

Surprisingly, at very high intracellular $\mathrm{Ca}^{2+}$ concentrations (1 $\mathrm{mM}$ ), a nonselective cation current was evoked in more than half of the patches excised from TRPM5 $5^{-/-}$animals. When measured immediately after patch excision, this conductance was halfactivated by $300 \mu \mathrm{M}$ intracellular $\mathrm{Ca}^{2+}$, and it desensitized only slightly after prolonged exposure to intracellular $\mathrm{Ca}^{2+}$ (Fig. $8 E, F)$. Under conditions in which $\mathrm{Na}^{+}$was the main cation on both sides of the membrane, the current reversed at $\sim 0 \mathrm{mV}$ (Fig. $8 E)$. Replacement of intracellular $\mathrm{Na}^{+}$with $\mathrm{NMDG}^{+}$essentially abolished the outward current $(n=8)$ (Fig. 9A), indicating that the current was carried by cations. This was further confirmed by experiments in which we found that substituting intracellular 


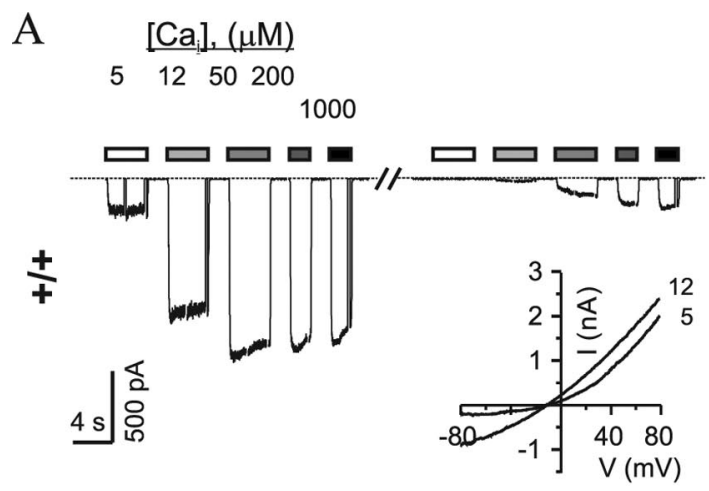

$\mathrm{C}$

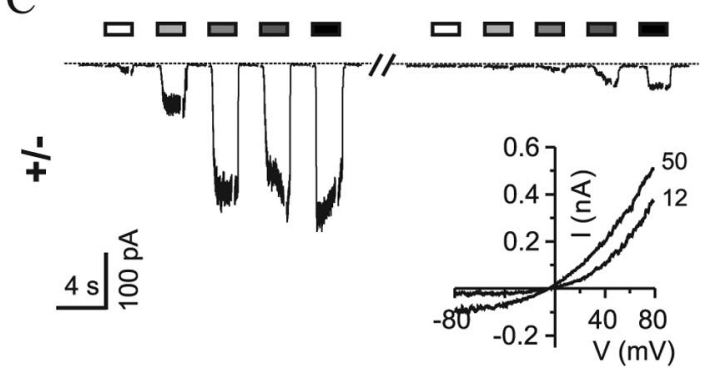

$\mathrm{E}$

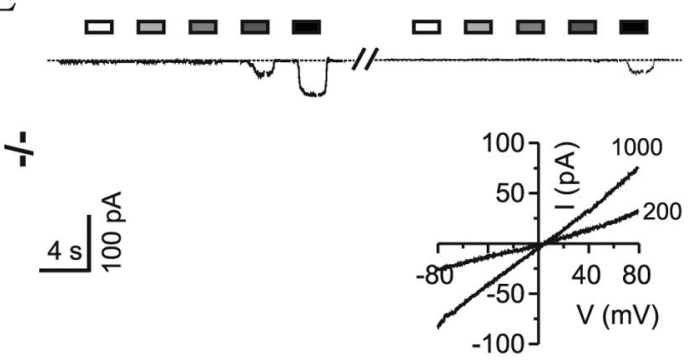

B
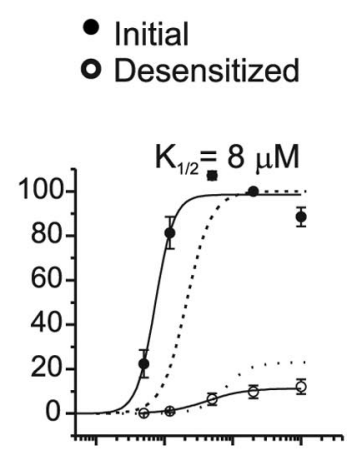

$\mathrm{D}$

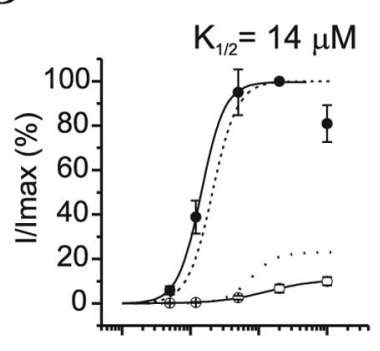

$\mathrm{F}$

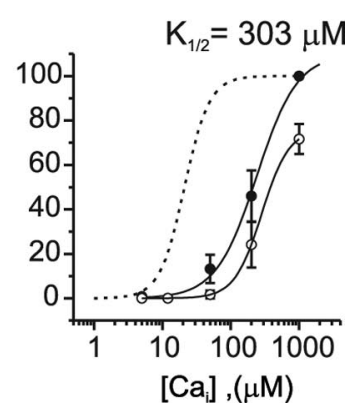

Figure 8. Native TRPM5 channels are activated by micromolar concentrations of intracellular $\mathrm{Ca}^{2+} . \boldsymbol{A}-\boldsymbol{F}$, Currents evoked in response to increasing concentrations of intracellular $\mathrm{Ca}^{2+}$ in excised patches from taste receptor cells from $\operatorname{TRPM}^{+/+}(A, B)$, TRPM5 $^{+/-}(\boldsymbol{C}, \boldsymbol{D})$, and TRPM5 ${ }^{-/-}(\boldsymbol{E}, \boldsymbol{F})$ mice. Raw data shown in $\boldsymbol{A}, \boldsymbol{C}$, and $\boldsymbol{E}$ was obtained either immediately on patch excision (traces to the left) or after repeated exposure of the patch to intracellular $\mathrm{Ca}^{2+}$ (trace to the right). Note the pronounced decrease in the currents, indicating that the channels have desensitized. Insets show the $I-V$ relationship at two calcium concentrations (indicated) for currents before desensitization. Note that the current in the cells from TRPM5 ${ }^{+/+}$and $T R P M 5^{+/-}$animals is strongly outwardly rectifying, whereas that in the cell from the $T R P M 5^{-/-}$animal is nearly linear. $B, D, F$, The $\mathrm{Ca}^{2+}$ doseresponse relationship from experiments as in $\boldsymbol{A}, \boldsymbol{D}$, and $\boldsymbol{G}$. Filled circles show the initial response to $\mathrm{Ca}^{2+}$, and open circles show the response after desensitization normalized to the peak response before desensitization. The sensitivity of the heterologously expressed channel before and after desensitization is shown by a dotted line (before desensitization, $K_{1 / 2}$ of $21 \mu \mathrm{M}, n=2.4, V_{\max }$ of 105; after desensitization, $K_{1 / 2}$ of $77 \mu \mathrm{M}, n=2.4, V_{\max }$ of 23) (Liu and Liman, 2003). Fits to data were as follows: $+/+$ initial $\left(K_{1 / 2}\right.$ of $8 \mu \mathrm{m} ; n=3.2 ; V_{\max }$ of 100$),+/+$ desensitized $\left(K_{1 / 2}\right.$ of $48 \mu \mathrm{m} ; n=1.4 ; V_{\max }$ of 11$),+/-\operatorname{initial}\left(K_{1 / 2}\right.$ of $14 \mu \mathrm{m} ; n=2.5$; $V_{\max }$ of 100$),+/-$ desensitized $\left(K_{1 / 2}\right.$ of $133 \mu \mathrm{m} ; n=1.2 ; V_{\max }$ of 10$),-/-\operatorname{initial}\left(K_{1 / 2}\right.$ of $303 \mu \mathrm{m} ; n=1.2 ; V_{\max }$ of 123$)$, and $-I-$ final $\left(K_{1 / 2}\right.$ of $283 \mu \mathrm{m} ; n=2.2 ; V_{\max }$ of 76$)$. Data are represented by the mean \pm SEM.

$\mathrm{Cl}^{-}$with gluconate or methane sulfonate ( $n=2$; data not shown) had no effect on the magnitude or reversal potential of the currents. To further characterize the current in TRPM $5^{-/-}$taste cells, we determined whether it was sensitive to block by intracellular ATP, which at micromolar concentrations blocks many $\mathrm{Ca}^{2+}$-activated nonselective cation channels (Thorn and Petersen, 1992; Liman, 2003) and blocks heterologously expressed TRPM4 channels (Nilius et al., 2004). ATP (18 $\mu \mathrm{M}$ free) blocked the $\mathrm{Ca}^{2+}$-activated currents in patches from TRPM5 $5^{-1-}$ taste cells (Fig. 9C), although the extent of block was highly variable
(Fig. 9D). Under the same conditions, incomplete and variable block of heterologously expressed TRPM4 channels was also observed (data not shown). The $\mathrm{Ca}^{2+}$-activated channels in TRPM5 $5^{-/-}$ cells were further characterized by "boxlike openings" and slow gating compared with the fast and flickery openings of TRPM5 channels (Fig. 9B) (supplemental Fig. 1, available at www.jneurosci.org as supplemental material). A conductance of $30 \mathrm{pS}$ was calculated based on the current amplitude at $-80 \mathrm{mV}$ of $-2.5 \pm 0.1 \mathrm{pA}$ $(n=6)$ (supplemental Fig. $1 C, D$, available at www.jneurosci.org as supplemental material). Because we could not detect activation of this current by uncaging $\mathrm{Ca}^{2+}$ or $\mathrm{IP}_{3}$ in whole-cell recording mode, it is presently unclear what role it plays in taste cell signaling.

\section{Discussion}

Bitter, sweet, and umami tasting compounds are detected by taste receptor cells that share a common transduction cascade for which the ion channel TRPM5 is a critical element (Perez et al., 2002; Zhang et al., 2003; Damak et al., 2006). Despite its significance for taste, the properties of TRPM5 channels in taste cells have not been described previously, and any information about how the channels are regulated has been obtained solely from the study of heterologously expressed channels (Perez et al., 2002; Hofmann et al., 2003; Liu and Liman, 2003; Prawitt et al., 2003; Zhang et al., 2003; Liu et al., 2005; Talavera et al., 2005). In this report, we characterized native TRPM5 channels using transgenic animals that allowed us to identify those taste cells that normally express TRPM5 and to compare currents in these cells in the presence and absence of an intact TRPM5 gene. Our results show that elevation of intracellular $\mathrm{IP}_{3}$ activates TRPM5 currents in taste cells and that this response can be entirely attributed to an elevation of intracellular $\mathrm{Ca}^{2+}$. Detailed study in excised patches has allowed us to define the properties of native TRPM5 channels and to compare these properties with those of heterologously expressed channels. Our results show that the native channels, like expressed channels, are activated by micromolar concentrations of intracellular $\mathrm{Ca}^{2+}$ and are selectively permeable to monovalent cations. These studies have also allowed us to identify a second, distinct, $\mathrm{Ca}^{2+}$-activated cation current in taste cells.

In general, the properties of endogenous TRPM5 channels are very similar to those of channels expressed in heterologous cell types transfected with mouse TRPM5. Both native and expressed channels are activated in intact cells by an elevation of $\mathrm{Ca}^{2+}$ or $\mathrm{IP}_{3}$ and in excised patches only by elevation of cytoplasmic $\mathrm{Ca}^{2+}$ 
A

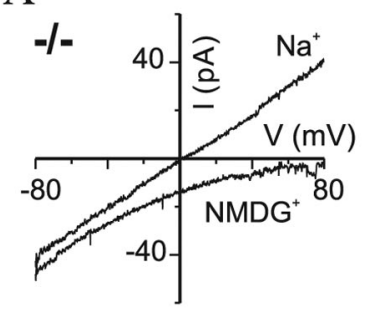

B

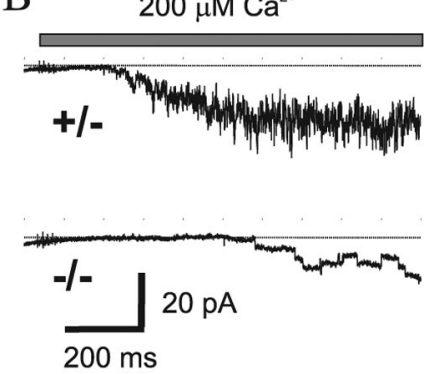

C

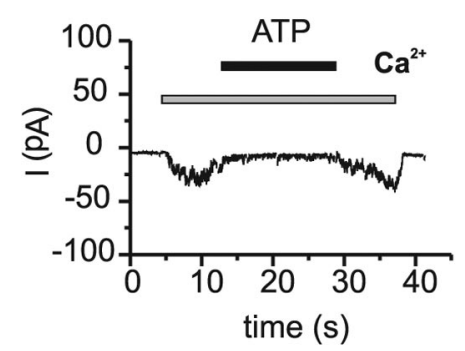

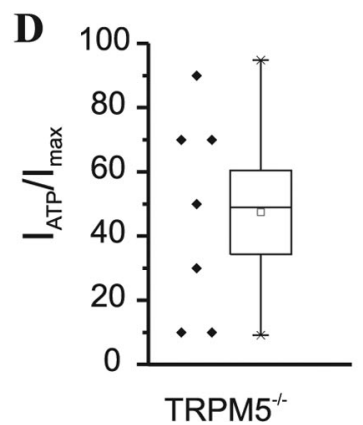

Figure 9. Properties of a TRPM5-independent $\mathrm{Ca}^{2+}$-activated channels in $\mathrm{TRPM}^{-/-}$taste cells. $A, \mathrm{Ca}^{2+}$-activated current in an excised patch from a TRPM5 ${ }^{-/-}$taste cell. Note that the outward current was eliminated when $\mathrm{Na}^{+}(150 \mathrm{~mm})$ on the cytoplasmic side of the patch was replaced by NMDG $(150 \mathrm{~mm})$, indicting that the channels were permeable to $\mathrm{Na}^{+}$. Intracellular $\mathrm{Ca}^{2+}$ was $200 \mu \mathrm{m} . \mathrm{B}, \mathrm{Ca}^{2+}$-activated channels in excised patches from taste cells from TRPM5 $^{+/-}$and TRPM5 $5^{-/-}$animals $\left(V_{\mathrm{m}}\right.$ of $\left.-80 \mathrm{mV}\right)$. Note the slow gating and box-like openings of the channels in the recording from the TRPM5 ${ }^{-1-}$ cell. C, Block by intracellular ATP of the $\mathrm{Ca}^{2+}$-activated current in a patch from a TRPM5 ${ }^{-/-}$taste cell. Intracellular $\mathrm{Ca}^{2+}$ was 1 $\mathrm{mm}$, and free ATP was calculated to be $18 \mu \mathrm{M}$. $\boldsymbol{D}$, Aggregate data from seven independent patches tested for sensitivity to ATP block. $I_{\text {ATP }}$ is the current remaining after exchange to the ATP-containing solution and $I_{\max }$ in the current after ATP exposure. The fraction of current that was insensitive to block by ATP $\left(I_{A T P} / I_{\text {max }}\right)$ was highly variable. Box plot shows the mean, SEM, and $90 \%$ confidence interval.

(Hofmann et al., 2003; Liu and Liman, 2003; Prawitt et al., 2003; Ullrich et al., 2005). Both native and expressed TRPM5 channels are nonselective among monovalent cations and relatively impermeable to divalent cations (Hofmann et al., 2003; Liu and Liman, 2003; Prawitt et al., 2003; Ullrich et al., 2005), and both native and expressed TRPM5 channels are, under the appropriate conditions, voltage modulated (Hofmann et al., 2003; Liu and Liman, 2003; Talavera et al., 2005). Native channels differ from heterologously expressed channels in that they are slightly more sensitive to activation by $\mathrm{Ca}^{2+}\left(K_{1 / 2}\right.$ of $8 \mu \mathrm{M}$ compared with $\left.21 \mu \mathrm{M}\right)$ and they show somewhat less outward rectification. Both of these properties endow the native channels with a greater capacity to convert small changes in intracellular $\mathrm{Ca}^{2+}$ to large changes in membrane potential. Differences in properties of native and expressed TRPM5 channels may reflect increased levels in taste cells of $\mathrm{PIP}_{2}$, which has been shown to increase $\mathrm{Ca}^{2+}$ sensitivity and decrease voltage-dependent gating of TRPM 5 and TRPM4 channels (Liu and Liman, 2003; Zhang et al., 2005; Nilius et al., 2006).

We also identified a $\mathrm{Ca}^{2+}$-activated cation conductance in taste cells that is distinct from the TRPM5-dependent conductance. This conductance, which was detected in excised patch recording mode from TRPM5 $5^{-/-}$cells, was relatively small and insensitive to activation by $\mathrm{Ca}^{2+}$. This may explain why we did not detect a response to uncaging $\mathrm{Ca}^{2+}$ or $\mathrm{IP}_{3}$ in TRPM $^{-/-}$cells. It is possible that this current is generated by channels that are encoded by the targeted TRPM5 gene, which is missing the first

three exons, but we could detect no expression of the TRPM5 protein using a C-terminal-directed antibody in TRPM5 $5^{-/-}$animals. It is more likely that this current is generated by channels encoded by a separate gene, possibly TRPM4, which is known to encode a $\mathrm{Ca}^{2+}$-activated nonselective cation channel. Heterologously expressed TRPM4 channels are relatively insensitive to intracellular $\mathrm{Ca}^{2+}$ (half activation of $\sim 100-300 \mu \mathrm{M}$ in excised patches) (Nilius et al., 2004; Zhang et al., 2005), much like the channels observed in TRPM5 ${ }^{-/-}$cells. Heterologously expressed TRPM4 channels are half-blocked by $2 \mu \mathrm{M}$ free ATP, and this block is incomplete even at high ATP concentrations (Nilius et al., 2004); similarly, we found that the $\mathrm{Ca}^{2+}$-activated channels in TRPM $^{-/-}$cells could be blocked by $18 \mu \mathrm{M}$ free ATP, although with variable efficacy. Finally, the conductance $(\sim 30 \mathrm{pS})$ and gating kinetics of expressed TRPM4 channels (Launay et al., 2002; Zhang et al., 2005) and of the $\mathrm{Ca}^{2+}$-activated channels in $\mathrm{TRPM}^{-1-}$ taste cells are similar. Interestingly, the $\mathrm{Ca}^{2+}$ activated current in TRPM5 $5^{-/-}$taste cells did not show any evidence of voltage dependence, in contrast to what has been reported for heterologously expressed TRPM4 and TRPM5 currents (Hofmann et al., 2003; Nilius et al., 2003). However, recent studies of native TRPM4 currents in mast cells has revealed that, in this context, the channels are not voltage dependent (Vennekens et al., 2007).

Our results predict that responses of taste cells to bitter, sweet, and umami tastants should be accompanied by the activation of a nonselective cation conductance. Despite decades of research, it is therefore curious that, in most studies, activation of a TRPM5like current to tastants has not been observed. For example, taste cells from several species have been shown to depolarize in response to sweet compounds, but this had been attributed to block of voltage-activated $\mathrm{K}^{+}$currents (Tonosaki and Funakoshi, 1988; Behe et al., 1990; Cummings et al., 1996; Gilbertson et al., 2001). Similarly, bitter compounds have been shown to block $\mathrm{K}^{+}$channels in taste cells from frog, mudpuppy, and rat (Avenet and Lindemann, 1987; Cummings and Kinnamon, 1992; Ogura et al., 1997; Gilbertson et al., 2001). There are, as far as we are aware, just a few examples in the literature in which nonselective cationic currents were observed in response to taste stimuli. In one study, glutamate, presumably acting on umami receptors, was shown to cause a transient depolarizing response and to open cation channels in a subset of rat taste cells (Bigiani et al., 1997). In another series of studies, intracellular dialysis of $\mathrm{IP}_{3}$ or $\mathrm{Ca}^{2+}$ into frog taste cells was found to activate a nonselective cation conductance, and a similar conductance was evoked by sweet stimuli (Tsunenari et al., 1996; Okada et al., 1998, 2001); these currents are likely mediated by TRPM5. In studies that failed to observe activation of a cationic conductance, it is possible that dialysis of high concentrations of $\mathrm{Ca}^{2+}$ buffers into the cells interfered with $\mathrm{Ca}^{2+}$-dependent activation of TRPM5 channels.

Our work, in combination with that of others, suggests that $\mathrm{IP}_{3}$ and $\mathrm{Ca}^{2+}$ are second messengers for taste transduction, converting the biochemical signal generated by the activation of taste receptors into a change in ionic permeability of the plasma membrane. This hypothesis has its antecedents in other sensory systems. For example, early functional studies of vertebrate vision suggested that intracellular $\mathrm{Ca}^{2+}$ was the second messenger for phototransduction (Pugh, 1987). However, it was subsequently determined by patch-clamp recording that vertebrate phototransduction depends on changes in a cyclic-nucleotide gated (CNG) conductance (Fesenko et al., 1985; Haynes and Yau, 1985). CNG-regulated ion channels have been noted in taste cells (Kolesnikov and Margolskee, 1995; Misaka et al., 1997), but the 
following lines of evidence establish $\mathrm{Ca}^{2+}$ along with $\mathrm{IP}_{3}$ as key second messengers in taste transduction: (1) bitter, sweet, and umami tastes elicit an elevation of intracellular $\mathrm{Ca}^{2+}$ (Akabas et al., 1988; Bernhardt et al., 1996; Ogura et al., 1997; Caicedo et al., 2002); (2) PLC $\beta 2$, which generates $\mathrm{IP}_{3}$, is essential for normal bitter, sweet, and umami taste (Zhang et al., 2003; Dotson et al., 2005); and (3) TRPM5, which forms a $\mathrm{Ca}^{2+}$-activated nonselective conductance in heterologous cells (Hofmann et al., 2003; Liu and Liman, 2003; Prawitt et al., 2003) and in taste cells (this report), is essential for normal bitter, sweet, and umami taste (Zhang et al., 2003; Damak et al., 2006). Thus, according to our data and that of others, it can be hypothesized that, during taste transduction, receptors activate a PLC signaling cascade that culminates in an elevation of intracellular $\mathrm{Ca}^{2+}$, opening of TRPM5 ion channels, and membrane depolarization.

Future research will be needed to precisely define the molecular mechanisms acting downstream of TRPM5 to modulate neurotransmitter release in taste cells. Bitter-, sweet-, and umami-sensing taste cells do not express voltage-gated calcium channels or other components of $\mathrm{Ca}^{2+}$-evoked secretion and the mechanism by which the neurotransmitter ATP is released has been enigmatic (Medler et al., 2003; Finger et al., 2005; Clapp et al., 2006; DeFazio et al., 2006). In two recent papers, it has now been proposed that ATP is secreted by a nonvesicular pathway that involves the voltage-dependent opening of connexin or pannexin hemichannels (Huang et al., 2007; Romanov et al., 2007). Consistent with this possibility, release of ATP can be evoked in isolated taste cells by membrane depolarization without elevation of intracellular $\mathrm{Ca}^{2+}$ (Romanov et al., 2007). Thus, in taste cells, intracellular $\mathrm{Ca}^{2+}$ does not directly regulate transmitter release but instead may do so indirectly through its effects on the gating of TRPM5 ion channels.

\section{References}

Akabas MH, Dodd J, Al-Awqati Q (1988) A bitter substance induces a rise in intracellular calcium in a subpopulation of rat taste cells. Science 242:1047-1050.

Avenet P, Lindemann B (1987) Patch-clamp study of isolated taste receptor cells of the frog. J Membr Biol 97:223-240.

Behe P, DeSimone JA, Avenet P, Lindemann B (1990) Membrane currents in taste cells of the rat fungiform papilla. Evidence for two types of Ca currents and inhibition of $\mathrm{K}$ currents by saccharin. J Gen Physiol 96:1061-1084.

Bernhardt SJ, Naim M, Zehavi U, Lindemann B (1996) Changes in IP3 and cytosolic $\mathrm{Ca}^{2+}$ in response to sugars and non-sugar sweeteners in transduction of sweet taste in the rat. J Physiol (Lond) 490:325-336.

Bigiani A, Delay RJ, Chaudhari N, Kinnamon SC, Roper SD (1997) Responses to glutamate in rat taste cells. J Neurophysiol 77:3048-3059.

Caicedo A, Kim KN, Roper SD (2002) Individual mouse taste cells respond to multiple chemical stimuli. J Physiol (Lond) 544:501-509.

Chen TY, Peng YW, Dhallan RS, Ahamed B, Reed RR, Yau KW (1993) A new subunit of the cyclic nucleotide-gated cation channel in retinal rods. Nature 362:764-767.

Clapp TR, Medler KF, Damak S, Margolskee RF, Kinnamon SC (2006) Mouse taste cells with $\mathrm{G}$ protein-coupled taste receptors lack voltagegated calcium channels and SNAP-25. BMC Biol 4:7.

Cummings TA, Kinnamon SC (1992) Apical $\mathrm{K}^{+}$channels in Necturus taste cells. Modulation by intracellular factors and taste stimuli. J Gen Physiol 99:591-613.

Cummings TA, Daniels C, Kinnamon SC (1996) Sweet taste transduction in hamster: sweeteners and cyclic nucleotides depolarize taste cells by reducing a $\mathrm{K}^{+}$current. J Neurophysiol 75:1256-1263.

Damak S, Rong M, Yasumatsu K, Kokrashvili Z, Perez CA, Shigemura N, Yoshida R, Mosinger B Jr, Glendinning JI, Ninomiya Y, Margolskee RF (2006) Trpm5 null mice respond to bitter, sweet, and umami compounds. Chem Senses 31:253-264.

DeFazio RA, Dvoryanchikov G, Maruyama Y, Kim JW, Pereira E, Roper SD,
Chaudhari N (2006) Separate populations of receptor cells and presynaptic cells in mouse taste buds. J Neurosci 26:3971-3980.

Dotson CD, Roper SD, Spector AC (2005) PLCbeta2-independent behavioral avoidance of prototypical bitter-tasting ligands. Chem Senses 30:593-600.

Fesenko EE, Kolesnikov SS, Lyubarsky AL (1985) Induction by cyclic GMP of cationic conductance in plasma membrane of retinal rod outer segment. Nature 313:310-313.

Finger TE, Danilova V, Barrows J, Bartel DL, Vigers AJ, Stone L, Hellekant G, Kinnamon SC (2005) ATP signaling is crucial for communication from taste buds to gustatory nerves. Science 310:1495-1499.

Gilbertson TA, Boughter Jr JD, Zhang H, Smith DV (2001) Distribution of gustatory sensitivities in rat taste cells: whole-cell responses to apical chemical stimulation. J Neurosci 21:4931-4941.

Hardie RC, Raghu P (2001) Visual transduction in Drosophila. Nature 413:186-193.

Haynes L, Yau KW (1985) Cyclic GMP-sensitive conductance in outer segment membrane of catfish cones. Nature 317:61-64.

Hofmann T, Chubanov V, Gudermann T, Montell C (2003) TRPM5 is a voltage-modulated and $\mathrm{Ca}^{2+}$-activated monovalent selective cation channel. Curr Biol 13:1153-1158.

Huang L, Shanker YG, Dubauskaite J, Zheng JZ, Yan W, Rosenzweig S, Spielman AI, Max M, Margolskee RF (1999) Ggammal3 colocalizes with gustducin in taste receptor cells and mediates IP3 responses to bitter denatonium. Nat Neurosci 2:1055-1062.

Huang YJ, Maruyama Y, Dvoryanchikov G, Pereira E, Chaudhari N, Roper SD (2007) The role of pannexin 1 hemichannels in ATP release and cell-cell communication in mouse taste buds. Proc Natl Acad Sci USA 104:6436-6441.

Hwang PM, Verma A, Bredt DS, Snyder SH (1990) Localization of phosphatidylinositol signaling components in rat taste cells: role in bitter taste transduction. Proc Natl Acad Sci USA 87:7395-7399.

Kolesnikov SS, Margolskee RF (1995) A cyclic-nucleotide-suppressible conductance activated by transducin in taste cells. Nature 376:85-88.

Launay P, Fleig A, Perraud AL, Scharenberg AM, Penner R, Kinet JP (2002) TRPM4 is a $\mathrm{Ca}^{2+}$-activated nonselective cation channel mediating cell membrane depolarization. Cell 109:397-407.

Liman ER (2003) Regulation by voltage and adenine nucleotides of a $\mathrm{Ca}^{2+}$ activated cation channel from hamster vomeronasal sensory neurons. J Physiol (Lond) 548:777-787.

Liman ER, Corey DP, Dulac C (1999) TRP2: a candidate transduction channel for mammalian pheromone sensory signaling. Proc Natl Acad Sci USA 96:5791-5796.

Liu D, Liman ER (2003) Intracellular $\mathrm{Ca}^{2+}$ and the phospholipid PIP2 regulate the taste transduction ion channel TRPM5. Proc Natl Acad Sci USA 100:15160-15165.

Liu D, Zhang Z, Liman ER (2005) Extracellular acid block and acidenhanced inactivation of the $\mathrm{Ca}^{2+}$-activated cation channel TRPM5 involve residues in the S3-S4 and S5-S6 extracellular domains. J Biol Chem 280:20691-20699.

Margolskee RF (2002) Molecular mechanisms of bitter and sweet taste transduction. J Biol Chem 277:1-4.

Medler K, Kinnamon S (2004) Transduction mechanisms in taste cells. In: Transduction channels in sensory cells (Frings S, Bradley J, eds), pp 153174. Weinheim, Germany: Wiley-VCH.

Medler KF, Margolskee RF, Kinnamon SC (2003) Electrophysiological characterization of voltage-gated currents in defined taste cell types of mice. J Neurosci 23:2608-2617.

Misaka T, Kusakabe Y, Emori Y, Gonoi T, Arai S, Abe K (1997) Taste buds have a cyclic nucleotide-activated channel, CNGgust. J Biol Chem 272:22623-22629.

Montell C, Rubin GM (1989) Molecular characterization of the Drosophila trp locus: a putative integral membrane protein required for phototransduction. Neuron 2:1313-1323.

Montmayeur JP, Matsunami H (2002) Receptors for bitter and sweet taste. Curr Opin Neurobiol 12:366-371.

Nilius B, Prenen J, Droogmans G, Voets T, Vennekens R, Freichel M, Wissenbach U, Flockerzi V (2003) Voltage dependence of the $\mathrm{Ca}^{2+}$ activated cation channel TRPM4. J Biol Chem 278:30813-30820.

Nilius B, Prenen J, Voets T, Droogmans G (2004) Intracellular nucleotides and polyamines inhibit the $\mathrm{Ca}^{2+}$-activated cation channel TRPM4b. Pflügers Arch 448:70-75. 
Nilius B, Talavera K, Owsianik G, Prenen J, Droogmans G, Voets T (2005) Gating of TRP channels: a voltage connection? J Physiol (Lond) 567:35-44.

Nilius B, Mahieu F, Prenen J, Janssens A, Owsianik G, Vennekens R, Voets T (2006) The $\mathrm{Ca}^{2+}$-activated cation channel TRPM4 is regulated by phosphatidylinositol 4,5-biphosphate. EMBO J 25:467-478.

Ogura T, Mackay-Sim A, Kinnamon SC (1997) Bitter taste transduction of denatonium in the mudpuppy Necturus maculosus. J Neurosci 17:3580-3587.

Okada Y, Fujiyama R, Miyamoto T, Sato T (1998) Inositol 1,4,5trisphosphate activates non-selective cation conductance via intracellular $\mathrm{Ca}^{2+}$ increase in isolated frog taste cells. Eur J Neurosci 10:1376-1382.

Okada Y, Fujiyama R, Miyamoto T, Sato T (2001) Saccharin activates cation conductance via inositol 1,4,5-trisphosphate production in a subset of isolated rod taste cells in the frog. Eur J Neurosci 13:308-314.

Perez CA, Huang L, Rong M, Kozak JA, Preuss AK, Zhang H, Max M, Margolskee RF (2002) A transient receptor potential channel expressed in taste receptor cells. Nat Neurosci 5:1169-1176.

Prawitt D, Monteilh-Zoller MK, Brixel L, Spangenberg C, Zabel B, Fleig A, Penner R (2003) TRPM5 is a transient $\mathrm{Ca}^{2+}$-activated cation channel responding to rapid changes in $\left[\mathrm{Ca}^{2+}\right]_{\mathrm{i}}$. Proc Natl Acad Sci USA 100:15166-15171.

Pugh Jr EN (1987) The nature and identity of the internal excitational transmitter of vertebrate phototransduction. Annu Rev Physiol 49:715-741.

Ranganathan R, Malicki DM, Zuker CS (1995) Signal transduction in Drosophila photoreceptors. Annu Rev Neurosci 18:283-317.

Rizzo MA, Springer GH, Granada B, Piston DW (2004) An improved cyan fluorescent protein variant useful for FRET. Nat Biotechnol 22:445-449.

Romanov RA, Rogachevskaja OA, Bystrova MF, Jiang P, Margolskee RF, Kolesnikov SS (2007) Afferent neurotransmission mediated by hemichannels in mammalian taste cells. EMBO J 26:657-667.

Rossler P, Kroner C, Freitag J, Noe J, Breer H (1998) Identification of a phospholipase C beta subtype in rat taste cells. Eur J Cell Biol 77:253-261.
Spielman AI, Mody I, Brand JG, Whitney G, MacDonald JF, Salter MW (1989) A method for isolating and patch-clamping single mammalian taste receptor cells. Brain Res 503:326-329.

Spielman AI, Nagai H, Sunavala G, Dasso M, Breer H, Boekhoff I, Huque T, Whitney G, Brand JG (1996) Rapid kinetics of second messenger production in bitter taste. Am J Physiol 270:C926-C931.

Talavera K, Yasumatsu K, Voets T, Droogmans G, Shigemura N, Ninomiya Y, Margolskee RF, Nilius B (2005) Heat activation of TRPM5 underlies thermal sensitivity of sweet taste. Nature 438:1022-1025.

Thorn P, Petersen OH (1992) Activation of nonselective cation channels by physiological cholecystokinin concentrations in mouse pancreatic acinar cells. J Gen Physiol 100:11-25.

Tonosaki K, Funakoshi M (1988) Voltage- and current-clamp recordings of the receptor potential in mouse taste cell. Brain Res 445:363-366.

Tsunenari T, Hayashi Y, Orita M, Kurahashi T, Kaneko A, Mori T (1996) A quinine-activated cationic conductance in vertebrate taste receptor cells. J Gen Physiol 108:515-523.

Ullrich ND, Voets T, Prenen J, Vennekens R, Talavera K, Droogmans G, Nilius B (2005) Comparison of functional properties of the $\mathrm{Ca}^{2+}$ activated cation channels TRPM4 and TRPM5 from mice. Cell Calcium 37:267-278.

Vennekens R, Olausson J, Meissner M, Bloch W, Mathar I, Philipp SE, Schmitz F, Weissgerber P, Nilius B, Flockerzi V, Freichel M (2007) Increased IgE-dependent mast cell activation and anaphylactic responses in mice lacking the calcium-activated nonselective cation channel TRPM4. Nat Immunol 8:312-320.

Zhang Y, Hoon MA, Chandrashekar J, Mueller KL, Cook B, Wu D, Zuker CS, Ryba NJ (2003) Coding of sweet, bitter, and umami tastes: different receptor cells sharing similar signaling pathways. Cell 112:293-301.

Zhang Z, Okawa H, Wang Y, Liman ER (2005) Phosphatidylinositol 4,5bisphosphate rescues TRPM4 channels from desensitization. J Biol Chem 280:39185-39192. 